\title{
Effect of Self Confident and Self Assessment for Performance with Social Skill as Moderating Variables
}

\author{
Siwi Dyah Ratnasari ${ }^{1)}$, Agus SalimAndriansyah ${ }^{2)}$ \\ STIE Malangkucecwara
}

\begin{abstract}
Superior human resource is a resource that not only have the hard skills, but also supported by a good soft skills. Everyone is expected to do a self-assessment by means of realizing and developing the potential of self-owned. In addition to developing a self-assessment, each person must also have a self-confident. If every individual has self-confident and self-assessment capabilities it will have an impact on the increase in the performance of the individual.The purpose of this study was to determine the effect of self-confident and selfassessment of the performance with social skills as moderating variables. This study differs from previous research by introducing a variable intrapersonal skills not only as independent variables but also as a moderating variable that strengthen/weaken relations skills intrapersonal variables on the performance of employees. Limitations of this study is not to enter the variable self-awareness and social awareness in the research.The analysis method used in this research is using MRA (Moderating Regression Analysis) with the study population are listed manufacturing company in Malang, amounting to 50 companies with sampling purposive sampling.The results showed that the self-confident will improve one's performance when coupled with good social skills. Without supported with social skills, self-confident even a negative effect on performance. The results also showed that self-assessment no significant effect on performance, either directly or with the effect of this moderation. This indicates that you should perform a self-assessment are other people (leaders or peers) not himself.
\end{abstract}

Keywords:Self-confident, Social skills, self-assessment, and Performance

\section{Introduction}

Superior human resource is a resource that not only have the hard skills, but also supported by a good soft skills. Problems usually soft skills become more complex when one is in a managerial position or when he has to interact with many people. The higher a person in a managerial position in the pyramid organization, the soft skills are becoming increasingly important to him. At this point someone will be required to interact and manage a variety of people with different personality traits and emotional intelligence has.

Basically soft skills such as character inherent in a person, so it takes great effort to fix it. However, soft skills is not something that can't be changed. Ability soft skills can be honed and improved in line with the will and work experience. In the world of work will be needed more than the soft skills of hard skills and soft skills that play a vital role in determining the success of one's career. According Vorhies and Morgan (2005), competitive advantage can be achieved as what is cool by all parties, with no neglect of soft skills and hard skills that develop into the support and resources for a sustainable competitive advantage. The results of the Harvard University, United States revealed that approximately $20 \%$ of success according Widyawati (2010), soft skills can be classified into two categories: intrapersonal and interpersonal skills. Intrapersonal skills include: self- awareness, self-confident, and self-assessment. While interpersonal skills include: social awareness, and social skills. Through soft skills should someone learned how to communicate intrapersonal andis determined by the hard skills and the remaining $80 \%$ by the soft skills. According to Spencer, accounted for $70 \%$ of soft skills in the success of a person and hard skills only accounted for $30 \%$ only.Interpersonal skill, how to be extraordinary people, how to capture and exploit business opportunities and many other positive things to support career.

Self-confidence is the capital that is needed by everyone. With high confidence and good at bringing themselves in the environment, someone will be sociable and adjust the interaction and this will have an impact on the rise of individual performance, which in turn impact on organizational performance. According Moeheriono (2009) the main factor of the young executive's success is self-confidence, adaptability, leadership and ability to influence others. Communication is the soft skills that can't be separated from public life or in career advancement, it indicates that the communication affect the performance of the individual (Wahyuni, 2009). Communication skills can be honed and developed by following trainings and seminars as well as the management of learning by doing. Though, powerful way to develop communication is to interact and direct activities with others. Someone who has good social skills in an organization will facilitate him in touch with others. With good communication, one will easily convey his ideas, it is easy to adapt to the work environment. According Prasetyanto(2008) and Gauss in (2011) Individuals who have good social skills in an organization 
will be able to improve its performance. Bambacas and Patricson(2008) Interpersonal communication skills areas that managers need to develop so that their interaction with staff may enhance commitment to the organization. Each individual in carrying out the work feel that their work is not independent of its performance. Self-assessment is used to determine the performance of an employee. Performance is the result of the quality and quantity of work achieved by an employee in carrying out their duties in accordance with the responsibilities assigned to him (Mangkunagara, 2004). According Guritno and Waridin (2005) performance is a comparison of the results achieved by employees working with a predetermined standard. Meanwhile, according to Justice (2006) is the result of the performance achieved by individuals that are tailored to the individual's role or task in a company at a particular time period, which is associated with a standard size or a specific value of the company in which the individual works. Performance is the comparison of the results achieved by employees working with the prescribed standards (Masrukhin and Waridin, 2004).

In achieving individual performance, an employee can't be separated from its soft skills among others is to have a self-confident, the ability to evaluate themselvesand that is no less important is the ability to communicate with others social skills. If someone has the social skillsare superior, then this will increase the self-confidence and also increased the ability to evaluate themselves (self-assessment). When someone have self-confident and the ability self-assessment as well as the ability to social skills are developed constantly by people than expected performance of individuals will increase.

\section{A. Soft Skills at Work}

\section{Literature Review And Hypothesis Development}

Simpson(2006) states thatis stilldifficulttodefine the termsoft skillsfor sure. Soft skills are individual behavior not seen his form and is intrapersonal and interpersonal skills can develop and improve the quality of one's-self. Broadly speaking soft skills can be classified into two categories: intra-personal and interpersonalskills. Intrapersonal-skills include: 1) self-awareness, 2) self-confident, 3 self-assessment. While interpersonalskills include: 1) social awareness, and 2) social-skill,(Widyawati,2010).Someonewhohas agoodsoft skillsarethosecan be effectivein the futurebecause itcanmanageboth internallypersonal lifeinto himand externallyin relationshipswithothers(Purdue, 2002). SoftskillsaccordingSailah(2008) can be interpretedas"Personal andinterpersonalbehaviorsthatdevelopandmaximizehumanperformance (e.g. Coaching, team building, decision making, initiative". This is in linewith the opinionsTripathy(2006), which statesthatsoft skillsarethe ability oftheaffectivenatureof a person, other than the abilityonintellectualformal technicalmasteryof a field ofscience thatallows a persontobe acceptedinthe environmentandwork environmentinclude: awareness, attitude, initiative, empathy, confidence, integrity, self-control,leadership, problem solving, risk takingand timemanagement.

\section{B. Self-confident}

Confidence is a mental or psychological condition in which an individual can evaluate the whole of him giving a strong belief in his ability to take action in achieving various goals in life. Confidence is one of the aspects of personality are very important in human life. People who believe themselves sure of their own abilities and have realistic expectations, even when their expectations are not realized, they remain positive minded and can accept it. According to the Dictionary of terms Thantaway Guidance and Counseling (2005), confidence is a mental or psychological condition of a person who gives a strong belief in himself to do or perform some action. People who do not believe themselves to have a negative self-concept, lack of trust the ability, because it is often shut down.

Self-confident that will support the high one becomes a brilliant career. For that each individual should build confidence by improving the competence, achievement and good behavior towards the surrounding environ Alert. According Sapariyah(2011). Self-esteem, self-efficacy has a positive effect on employee performance. Build confidence should be limited to not too excessive (over confidence) so that even selfdefeating. Build confidence should be done by everyone because it will improve the performance and good reputation. According to Goleman, (2001). Emotional intelligence someone will have a positive impact on performance.

\section{Self Assessment}

One's view of himself or herself frequent assessment of misunderstanding. Most of them assume other people's opinion as a picture of him. In fact, who knows how he is the individual itself. Each individual is expected to know the strengths and weaknesses of the individual even have to know how to overcome the shortcomings that exist in him. Not only that, the need to develop is how these individuals bring himself. Selfevaluation is basically evaluate the performance itself, whether it is in accordance with established standards. 
Basically disadvantages and advantages not only in terms of purely physical, but the attitude and mindset are also decisive. Weaknesses and strengths within themselves known only by the individuals themselves (Pratama, 2009)

\section{Social skills}

The ability of a person in a social activity can be categorized into two are individuals who are good at communicating and individuals are difficult to communicate. For individuals who are easy to communicate, it will easily be able to adapt to the environment, can easily convey his ideas, can deliver criticism without hurting the feelings of others, and vice versa for individuals who are hard to communicate. According to Bhushan at. all (2011) Soft skills are personal attributes that career prospects in the life, and one of the keys to success in the work is the ability to cooperate with others, either peers or superiors. Meanwhile, according Marrel (2008) social skills that is specific behaviors, initiatives, lead to results that are expected as a form of social behavior. Sulityowati,(2007). Motivation and Social Skills Has a Positive Effect on Performance.

Good communication skills in an organization will be able to improve the performance of a person. According Prasetyanto(2008) and Purwanto(2011), good communication within an organization will improve the performance of individuals. According Aimaozhang, (2012). Hard and Soft skills to Communicate with end users to resolve conflicts, and to bring different functions together toward a common goal.

\section{E. Performance}

Everyone in performing duty to feel that their work is not independent of its performance assessment. The performance assessment is used to determine the performance of an employee. Performance of individuals / employees is the result of the quality and quantity of work achieved by an employee in carrying out their duties in accordance with the responsibilities assigned to him (Mangkunegara, 2004). According to Goleman (2001).Emotional intelligencesomeonewillhave a positive impactonperformance.

While Soedjono (2005) mentions six (6) criteria that can be used to measure the performance of individual employees namely:

1. Quality, results of the work carried out near-perfect or meet expected goals of the job

2. Quantity, Amount produced or the number of activities that can be completed.

3. Timeliness, which can finish at a predetermined time and maximize the time available for other activities.

4. Effectiveness, maximum utilization of existing resources in the organization to increase profits and reduce losses.

5. Independence, which can carry out the work without assistance in order to avoid adverse outcomes.

6. Commitment to work, is between employee commitment to the organization and responsibilities of employees of the organization.

To improve individual performance, an employee can't be separated from the soft skills possession that consists of intrapersonal skills and interpersonal skills. Intrapersonal ability that soft skills associated with him, including a high confidence (self-confident), the ability to evaluate themselves (self-assessment) and selfawareness. While interpersonal skills are soft skills associated with other people. Interpersonal skills consist of the ability to communicate with others (social skills) and social awareness. This study did not include the variable self-awareness and social awareness in the research model. Expected further research can incorporate this variable. If someone has the social skills are superior, then this will increase the self-confidence and also increased the ability to evaluate themselves (self-assessment). Self-confident, the ability to evaluate themselves (self-assessment) and the ability to communicate with others (social skills) if it is developed continuously by the individual, the expected performance of individuals / employees will be increased, so that the development of hypotheses from this study can be seen in figure 1

Figure 1Hypothesis model

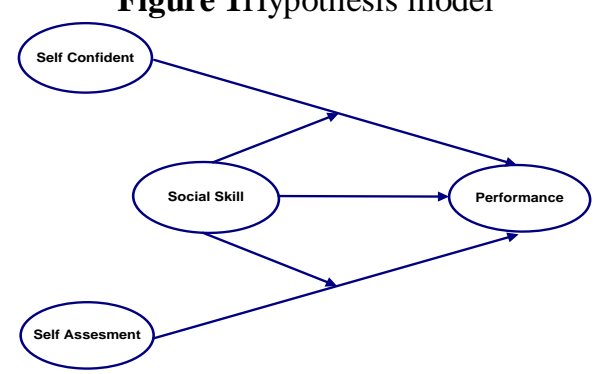

While the hypothesis proposed in this study are:

1. Self -confident directly influence the performance

2. Self-assessment directly influence the performance 
3. Social skills directly influence the performance

4. Social skills able to moderate the influence of self-confident against performance

5. Social skills able to moderate the influence of the self-assessment against performance of employees

\section{Methodology}

This type of research is descriptive quantitative research. The method of analysis used in this study is the method of multiple linear regression analysis with moderating variables or Multiple Regression Analysis (MRA). Moderating variable is the independent variable that will strengthen or weaken the relationship between the other independent variables on the dependent variable. This method is done by adding the multiplication variable between independent variables with moderating variable. Research data processing performed by using the software, named SMART PLS is the analysis stage MRA (Moderating Regression Analysis). Data was collected through questionnaires.

The parameters used in this study are:

1. Self -confident(X1); Self-confident that a strong belief in the ability of yourself to take action in achieving life goals.

2. Self -assessment(X2); Self-assessment is assessment over oneself to identify the strengths and weaknesses of the

3. Social skills (X3); Social skills is the ability to cooperate/communicate with other people, either colleagues or superiors/subordinates.

4. Performance(Y); Performance is a comparison of the quality or quantity of the work accomplished by an employee with a predetermined standard.

\section{Data Collection and Analysis Techniques}

The population in this study is a manufacturing company registered in Malang as many as 50 companies. Methods of data collection is done through questionnaires. Questionnaires administered through direct visits, or correspondence. The sampling technique was first performed on stage with multiple stage methodis selecting $10 \%$ of manufacturing companies conducted randomly chosen in order to obtain 5 manufacturing companies in the sample. For the second stage of the 5 samples selected manufacturing company, sampling is done in purposive sampling, each selected $10 \%$ of the total number of employees the management of five companies selected. The sample was selected randomly. So that the number of samples obtained by 62 respondents.

\section{Results And Discussion}

1. The results showed that the self -confident direct impact negatively on performance

MRA analysis results show the path coefficient of -2619 with a $\mathrm{P}$ value of 0.003 is smaller than alpha 0.05. This indicates that build confidence should be done by everyone and should be followed by the development of other soft skills. People who believe themselves sure of their own abilities and have realistic expectations, even when their expectations are not realized, they remain positive minded and can accept it. High confidence boosted by high without good social skills will cause a person to be over confidence and this would be self-defeating and degrade the performance of the individual.

\section{Self-assessment does not directly influence the performance of}

MRA analysis results show the path coefficient of -0530 with a $\mathrm{P}$ value of 0.113 is greater than alpha 0.05. Basically disadvantages and advantages not only in terms of purely physical, but the attitude and mindset are also decisive. These results do not support previous research where the weaknesses and strengths within themselves known only by the individuals themselves (Pratama, 2009).

\section{Social skills direct impact negatively on performance}

MRA analysis results show the path coefficient of -2125 with a $\mathrm{P}$ value of 0.025 is smaller than alpha 0.05. This indicates that the higher a person's social skills, the performance will decrease.

4. Social skills able to moderate the influence of self -confident on the performance

MRA analysis results show the path coefficient of 4903 with a $\mathrm{P}$ value of 0.01 is smaller than alpha

0.05 .

The results of this study showed that self-confident, followed by a good social skills will improve one's performance. In reaching individual performance, one can't be separated from its soft skills among others, is to have a self -confident. Self-confident will lead the person to explore other capabilities. If Self-confident in the ability of social skills support with good results will be outstanding on individual performance improvement.

The results of this study support previous research where good communication skills within an organization will be able to improve the performance of a person (Prasetyanto, 2008 and Purwanto, 2011). Self-confident that supported with good social skills within an organization will be able to improve the performance of individual 5. Social skills are not able to moderate the influence of the self-assessment of the performance 
MRA analysis results show the path coefficient of -2975 to $-1746 \mathrm{P}$ value of greater than alpha 0.05 . The results of this study indicate that social skills are not able to moderate self-assessment on performance. This indicates that the self-assessment can only be done by yourself. This study supports previous research where the weaknesses and strengths in a person known only by the individuals themselves (Pratama, 2009)

\section{Conclusions And Recommendations}

\section{Conclusion}

The results showed that:

1. Self-confident direct impact negatively on performance. This indicates that build confidence should be done by everyone and should be followed by the development of other soft skills. People who have confidence confident about their own abilities and have realistic expectations, even when their expectations are not realized, stayed positive and can accept it. High confidence boosted by high without good social skills will cause a person to become over- confidence and this would be self-defeating and degrade the performance of the individual.

2. Self-assessment does not directly influence the performance. Basically weaknesses and strengths not only in terms of purely physical, but the attitude and mindset are also decisive.

3. Social skills direct impact negatively on performance. This indicates that the higher a person's social-skills, the performance will decrease.

4. Social skills able to moderate the influence of self-confident on the performance. The results of this study indicate that high self-confident, followed by a good social skills will improve one's performance. In reaching individual performance, one can't be separated from its soft skills among others, is to have a selfconfident. High confidence in a person will lead the person to explore other capabilities. If self-confident in the ability of social skills support with good results will be outstanding to increase individual performance.

5. Social skills are not able to moderate the influence of the self-assessment of the performance. The results of this study indicate that social skills are not able to moderate self-assessment on performance. This indicates that the self-assessment can only be done by yourself.

\section{Recommendation}

1. Based on the results of the study showed that social skills are very large effect on the increase in selfconfident and individual performance it should be every individual should build social skills in order to improve self-confident or confidence in him. Self-confident high backed with good social skills will improve individual performance. Instead of high self-confident without the support of a good social skills it will degrade performance.

2. Self-confident should be done by someone else instead of yourself in order to obtain a true picture.

\section{References}

[1]. Bambacas, Mary and Patricson, Margaret. 2008. Interpersonal Communications Skills Organisational that EnchanceComitment, Journal of Communications Management. Vol. 12 ISS: 1. Pp.51-57

[2]. Daniel Goleman. 2001. Primal Leadership: The Hidden Driver of Great Performance Harvard Business Review 9(11). 42-51

[3]. Jawale,ArunBushan, VikasBendgude, andNadeenHussain. 2011. Soft Skill Appraisal for Dentistry: A Tool for Positive Practice Management. The Journal of dental practice 10.5005 / jp - journals - 1024-1079

[4]. Moeheriono, 2009. Competency-Based Performance Measurement. Gallic Indonesia.

[5]. Prasetyanto, Gina Court. 2008. Communication Influences Performance on Soekardi Ceramics Company Malang. Thesis, University of Muhammadiyah Malang. http://eprints.umm.ac.id/id/eprint/6008

[6]. Purdue, 2002. Soft Skills. Accessed November 1, 2013 ( online )

fromwww.cco.purdue.edu/Articles/Article-SoftSkills.shtml

[7]. Purwanto, Sony. 2011. Effect of Comunication, Motivation and Job Satisfaction on Employee Performance (Studies in Foundations Tower Project in East Timor PT CahayaInspirasi Indonesia), Journal of Management Application. Jurnaljam.ub.ac.id

[8]. Sailah,Illah. 2008. Development of Soft Skills in Higher Education. Bogor: Soft Skills Development Team Directorate General of Higher Education

[9]. Sapariyah, Ani. 2011. Effect of Self Esteem, Self-Efficacy and Locos of Control for Employee Performance in Perspective Balance Scorecard on Housing. Pawnshop Boyolali. Journal of Business Economics and Banking. Vol.19.n018.e-journal.stie-aub.ac.id/ejournal/index.php/probank/article/view/ss

[10]. Simpson, Simon. 2006. The Measurement and Recognation of Soft Factors. United Kingdom: University of Surrey

[11]. Sulityowati, Sri. Setiawan, Imam. 2007. Effect of Emotional Intelligence on Individual Performance. Journal AKSES.vol 2.no 3.2007.www.unwahas.ac.id/publikasiilmiah/index.php/AKSES/article/view/499

[12]. Tripathy. (2006). When Going Gets Tought, The Soft Get Going. Accessed on 4 April 2014 (online) from http://www.selfgrowth.com/articles/Tripathy1.html

[13]. Widyawati, 2010. Soft Skills Learning Strategy Paper. Graduate programs-public universities. Padang, http://asep.synthasite.com/asep-ma/pentingnya-pendidikan-soft-skill. The access on the date May 14, 2011. 